Firmino Wagner Gomes da Silva

\title{
A Imago Dei na Antropologia Teológica de \\ Wolfhart Pannenberg
}

Dissertação de Mestrado

Dissertação apresentada ao Programa de PósGraduação em Teologia da PUC-Rio como requisito parcial para obtenção do título de Mestre em Teologia.

Orientador: Dr. Mario França Miranda 
Firmino Wagner Gomes da Silva

\section{A Imago Dei na Antropologia Teológica de Wolfhart Pannenberg}

Dissertação apresentada como requisito parcial para obtenção do grau de Mestre pelo Programa de Pósgraduação em Teologia do Departamento de Teologia do Centro de Teologia e Ciências Humanas da PUC-Rio. Aprovada pela Comissão Examinadora abaixo assinada.

Prof. Mario França Miranda Orientador

Departamento de Teologia - Puc - Rio

Prof. Paulo Cezar Costa Departamento de Teologia - Puc - Rio

Prof. Antônio José Afonso da Costa

ISTARJ

Prof. Paulo Fernando Carneiro Andrade

Coordenador Setorial de Pós-Graduação e Pesquisa do Centro de Teologia e Ciências Humanas - PUC-Rio

Rio de Janeiro, 
Todos os direitos reservados. É proibida a reprodução total ou parcial do trabalho sem a autorização do autor, do orientador e da universidade.

Firmino Wagner Gomes da Silva

Graduou-se em Teologia pelo Seminário Teológico Batista do Sul do Brasil em 2002. Em 4 de outubro de 2005 foi ordenado ao Ministério Pastoral pela Convenção Batista Brasileira e atualmente é pastor da Igreja Batista na Campanha, na região sul do estado de Minas Gerais.

Ficha Catalográfica

Silva, Firmino Wagner Gomes da

A Imago Dei na antropologia teológica de Wolfhart Pannenberg / Firmino Wagner Gomes da Silva ; orientador: Mario França Miranda. 2009.

120 f. ; $30 \mathrm{~cm}$

Dissertação (Mestrado em Teologia)Pontifícia Universidade Católica do Rio de Janeiro, Rio de Janeiro, 2009.

Inclui bibliografia

1. Teologia - Teses. 2. Imago Dei. 3. Antropologia teológica. 4. Criação. 5. Cristologia. 6. Pannenberg, Wolfhart. I. Miranda, Mario França. II. Pontifícia Universidade Católica do Rio de Janeiro. Departamento de Teologia. III. Título. 
Para minha amada e linda esposa Elaine e meu lindo filho Arthur pela alegria que eles dão a minha vida. 


\section{Agradecimentos}

À Trindade Santa pelo seu infinito amor que me gerou, sustenta e governa minha vida, dando-me a honra de desfrutar de comunhão amorosa com Ela e com a realidade que me cerca.

Ao meu orientador Professor Mario França de Miranda pelo estímulo e parceria para a realização deste trabalho.

Ao CNPq e à PUC-Rio, pelos auxílios concedidos, sem os quais este trabalho não poderia ter sido realizado.

Ao meu avô Antonio Malheiros e minha avó Helle-Nice pela grande fonte de bênçãos que eles são em minha vida, sendo referencial de vida cristã, pais e amigos.

A todos os meus familiares, tios e primos que sempre me tratam com amor e confiança.

Aos meus pais Eraldo e Dulcinéa que em toda a minha vida me dispensaram muito amor e atenção, dedicando as suas vida para me ensinar a Palavra de Deus e me proporcionar uma vida honrada.

Aos meus irmãos Clayton, Simone, Jacqueline e Carlinhos, que foram grandes incentivadores nesta empreitada, como também são em todos os momentos de minha vida.

Aos meus sobrinhos Stephanie, Jonathan e Raphael que sempre são fonte de alegria, esperança e paz.

A toda a comunidade da Igreja Batista na Campanha, especialmente aquele que nestes poucos tempos de convivência se tornaram amigos verdadeiros, dispensando a mim, a minha Elaine e ao meu Arthur um imensurável carinho.

A minha sogra Edna que tem me acolhido como filho. 
Aos meus amigos Victor e Raphael que independente do tempo e da distancia sempre são amigos, ou melhor, irmãos.

Ao Edson e a Elionai que são pessoas importantes para mim e minha esposa.

A professora Marília que com tanta dedicação revisou todo o trabalho, dando uma rica contribuição. Também ao seu esposo Roberto Silva que é para mim um grande amigo.

Aos meus primos emprestados Guilherme e Victor por sua tão sincera amizade.

Aos professores que participaram da comissão examinadora.

A todos os professores e funcionários do Departamento pelos ensinamentos e pela ajuda.

Aos colegas da PUC-Rio.

Finalmente as duas pessoas mais importantes de minha vida, minha esposa Elaine pelo seu amor, sua dedicação e o apoio constante, sobretudo nos momentos mais difíceis da minha vida, de meu ministério e de minha vida. e nosso bebê que mesmo sendo ainda tão pequenino já ocupa um grande espaço em nosso coração.

Termino ciente de que não agradeci à todos nominalmente, mas convicto da gratidão que tenho no meu coração por cada pessoa que me ajudou a chegar até aqui. 


\section{Resumo}

Silva, Firmino Wagner Gomes; Miranda, Mario de França. A Imago Dei na Antropologia Teológica de Wolfhart Pannenberg. Rio de Janeiro, 2009. 120p. Dissertação de Mestrado - Departamento de Teologia, Pontifícia Universidade Católica do Rio de Janeiro.

O presente estudo busca, através da antropologia teológica de Wolfhart Pannenberg, aprofundar o conteúdo da doutrina da imago Dei e sistematizá-la. Para alcançar tal objetivo este trabalho, logo em sua introdução, elencará algumas informações a respeito da pessoa, da vida e da teologia de Wolfhart Pannenberg. Numa segunda etapa nos aproximaremos de nosso tema, fazendo um percurso histórico que visará apresentar um pouco como se deu a tematização da doutrina da imago Dei em alguns momentos da história do pensamento cristão. Em seguida, iniciaremos outra etapa e aprofundaremos o pensamento antropológico de nosso autor, observando as linhas gerais de sua antropologia. Mais precisamente os seus pressupostos antropológicos que exprimem a sua visão da realidade humana e os seus pressupostos teológicos que consistem na sua interpretação teológica das características ontológicas do ser humano. Interpretação que se dá a partir de uma leitura bíblica panorâmica e da reflexão teológica na história. Essas informações nos fornecerão os subsídios necessários para compreendermos a doutrina da imago Dei em sua teologia e assim nos permitirão chegar na quarta etapa de nosso trabalho, quando veremos os seus posicionamentos. Inicialmente explicitaremos porque a seu ver o homem está numa posição de destaque em relação às demais criaturas, em seguida veremos porque Pannenberg entende Adão como a imago Dei cópia e qual é na sua visão a implicação da imago Dei na existência de Adão. Na segunda parte do quarto capítulo, veremos os motivos que levam Pannenberg a afirmar que Jesus Cristo é a verdadeira imagem de Deus, ou seja, a imagem-modelo. Raciocínio que faz com que na sua antropologia teológica Jesus Cristo seja compreendido como o autêntico homem. Outra questão que levantaremos nesta segunda parte da quarta etapa é a importância que nosso autor dá à condição filial de Jesus, fato que está profundamente ligado na sua compreensão da eficácia salvífica da sua missão 
ordenada pelo Pai, de reconciliar o mundo. Fazendo com que todo homem através da ação do Espírito seja capaz de desfrutar de uma comunhão amorosa com Deus, e desta forma alcançar o destino que foi determinado em sua criação segundo a imagem divina.

\section{Palavras-chave}

Imago Dei; antropologia teológica, criação; cristologia; Wolfhart Pannenberg 


\section{Abstract}

Silva, Firmino Wagner Gomes; Miranda, Mario de França (Advisor). The Imago Dei in Theological Antropology of Wolfhart Pannenberg. Rio de Janeiro, 2009. 120p. MSc. Dissertation - Departamento de Teologia, Pontifícia Universidade Católica do Rio de Janeiro.

This study seeks through the theological anthropology of Wolfhart Pannenberg, Deepens the content os the doctrine of Imago Dei and systematize it. To achieve such a goal, this work in his introduction will present some informations about the person, the life and the theology of Wolfhart Pannenberg. In the second stage we will get closer our goal doing a historical journey that will aim to present a little like happened the development of the doctrine of the Imago Dei at some moments from the history of the Christian thought. We will begin another stage, the anthropological thought of our author observing the general lines of his anthropology. More precisely his anthropological presuppositions that express his vision of the human reality and his theological presuppositions that consist of his theological interpretation of the ontological characteristics of the human being. Interpretation that happens from a panoramic reading of the Bible and of the theological reflection in the history. These informations will supply us with the necessary subsidies in order that we understand the doctrine of the Imago Dei in his theology that will enable us to reach the fourth stage of our work when we will see their placements. Initially we will explain the motives in his opinion man is in a position of prominence in relation to other creatures, then we will understand the reason Pannenberg affirm to be Adam Imago Dei copy, and wich is in his point of view the implication of the Imago Dei in Adam's existence. In the second part of the fourth chapter we will study the motives that take Pannenberg affirm that Jesus Christ is the God's true image, in other words the image-model. Through this reasoning in his theological anthropology Jesus Christ is understood like the authentic man. Another question that we will raise in this second part of the fourth stage is the importance that our author gives to the condition of Jesus as son of God, Fact that is deeply connected in his understanding of the salvivic efficiency of his mission ordered by the Father, to 
reconcile the world. Doing that so every men through the action of the Spirit is able to enjoy a loving communion with God, and in this way reach the destiny that was determined in his creation according to the divine image.

\section{Keywords}

Imago Dei, theological antropology, creation, cristology and Wolfhart Pannenberg 


\section{Sumário}

1 Introdução

$\begin{array}{ll}\text { 1.1. Vida } & 18\end{array}$

1.2. Trajetória Acadêmica 19

1.3. Obras 21

1.4. Círculo de Heidelberg 21

1.5. Linhas Gerais da Teologia de Pannenberg 22

2 A Imago Dei na História da Teologia 26

2.1. Na Patristica $\quad 27$

2.1.1. Escola Alexandrina 28

2.1.2. Escola Antioquena 31

2.1.3. Escola Ocidental 34

2.2. Na Idade Média 36

$\begin{array}{ll}\text { 2.2.1. Boaventura } & 37\end{array}$

2.2.2. Tomás de Aquino $\quad 39$

2.3. Na Reforma $\quad 41$

2.3.1. Em Lutero 42

2.3.2. Em Calvino 44

2.4. Na Teologia Contemporânea $\quad 47$

2.4.1. Tendência Minimalista 48

2.4.2. A Tendência Moderada 49

2.4.3. A Tendência Maximalista $\quad 50$

3 Linhas Gerais da Antropologia Teológica de Pannenberg 54

3.1. Pressupostos Antropológicos 56

3.1.1. A Dignidade do Homem 56

3.1.2. Homem, Unidade Corpo e Alma 63

3.1.3. Abertura ao Mundo 66 
3.2.1. Releitura do Gênesis, Revendo a Concepção do

Estado Original 72

3.2.2. O Ser Imagem de Deus Como Destino do Homem 76

3.2.3. A Miséria Decorrente do Pecado 79

3.2.4. O Homem Como História 83

3.2.5. Cristo, a Realização Proléptica do Futuro do Homem 85

4 A Imago Dei na Antropologia de Pannenberg 88

4.1. A Imago Dei em Adão 90

4.1.1. Homem, Uma Criatura Diferente 90

4.1.2. Adão, a Imago Dei Cópia 93

4.1.3. Imago, o Substrato da Abertura ao Mundo 95

4.2. Cristo, a Imago Dei Modelo 98

4.2.1. Jesus o Autêntico Homem 98

4.2.2. Jesus o Filho Preexistente do Pai 102

4.2.3. O Sentido Salvífico da Encarnação 105

5 Conclusão 111

6 Referências Bibliográficas 113 


\section{Abreviações}
APT
Antropologia en Perspectiva Teologica
EhcP
El Hombre como Problema
TS1
Teologia sistemática I
TS2
Teologia sistemática II

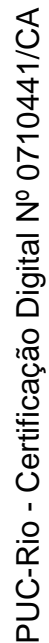

